\title{
KONSTRUKSI NALAR POLITIK KENEGARAAN ARAB-ISLAM PERSPEKTIF AL-JABIRI
}

\author{
M. Hasan Ubaidillah \\ Fakultas Syariah IAIN Sunan Ampel Surabaya, JI. A. Yani I I 7 Surabaya
}

\begin{abstract}
Abstrak; Konstruksi nalar politik kenegaraan Arab-Islam yang di formulasikan oleh Muhammad Abed al-Jabiri merupakan bagian dari Ikhtiar dalam menyamakan persepsi masyarakat Arab minimal pada tingkat Pemikiran dan epistimologis sebelum sampai pada persatuan bangsa Arab (al-Wihdah al-Arabiyyah ) pada tingkat empiris yaitu pada tataran sosiologis dan politis. Idiologi nalar politik kenegaraan ArabIslam dalam konteks ini berusaha diwujudkan tidak hanya pada tingkat sosiologis dan epistimilogis bangsa Arab saat ini, akan tetapi juga berusaha mentransformasikan kemajuan Arab-Islam pada masa lampau dalam tradisi (turats), dimana ia akan mencari unsur-unsur kemajuan dalam upaya merekatkan dan mempersatukan aspek-aspek kebudayaan Arab yang terceraiberai sehingga memungkinkan untuk dijadikan pijakan idiologis kebangkitan "Nasionalisme Arab-Islam", dengan melakukan upaya reinterpretasi dan pembacaan terhadap konsep al-Aqidah, al-Kabilah dan al-Ghanimah secara praksis dan aplikatif dalam konteks kekinian.
\end{abstract}

Kata Kunci: Nalar Politik kenegaraan, Arab-Islam, al-Jabiri

\section{Pendahuluan}

Badai revolisi yang menyebabkan tumbangnya rezim "dictator" Tunisia, Mesir dan Libya merupakan fakta histories yang menjadi salah satu pertanda kegagalan Negara-negara Arab dalam mengelola pemerintahannya. Kegagalan tersebut bermuara pada system politik yang dibangun berdasarkan prinsip otoritarianisme dengan mengatasnamakan Tuhan dan agama sebagai dasar argumentasi keabsahan dan legalitasnya. Dalam konteks ini hegemoni Negara atas rakyat menjadi sangat kuat dan kokoh sehingga rakyat tidak dapat melakukan kritik terhadap 
penguasa apalagi melakukan control terhadap berbagai macam kebijakan penguasa yang merugikan masyarakat.

Sebagain pemikir Arab - Islam berpendapat bahwa demokrasi merupakan jiwa dari system politik dan pemerintahan Islam, meskipun dalam satu sisi sebagian pemikir Arab Islam menolak asusmsi-asumsi filosofisnya tentang kedaulatan rakyat sebagaimana yang dipersyaratkan oleh system demokrasi. Mereka percaya bahwa suara mayoritas dapat menjadi dasar bagi pelaksanaan kekuasaan politik yang sah didalam suatu negara Islam apabila tetap berada dalam batas-batas kedaulatan legal dan politik Allah SWT. Prinsip ini didasarkan pada nash al-Qur'an yang menjelaskan bahwa untuk menyelesaikan semua persoalan haruslah dilakukan melalui saling bermusyawarah. ${ }^{1}$

Maka merupakan suatu keharusan pasca wafatnya Rasulullah Muhammad SAW para penggantinya (Khalifah al-Rasul) ketika mereka terpilih sebagai pemimpin ummat Islam senantiasa berpegang teguh pada al-Qur'an dan al-Sunnah, sebagaimana yang telah dicontohkan secara factual oleh Abu Bakar ketika terpilih sebagai khalifaturrasul pertama yang secara jelas telah mendifinisikan batas-batas peranan dan kekuasaanya sebagai kepala Negara Islam dengan menyatakan:

“Aku telah diangkat sebagai penguasa kalian, meskipun aku bukanlah yang terbaik diantara kalian. Bantulah aku bila benar dan koreksilah bila berbuat kesalahan. Orang yang lemah diantara kalian akan menjadi kuat dihadapanku sehingga aku memberikan haknya apabila Allah SWT menghendaki, dan orang yang kuat diantara kalian akan menjadi lemah dihadapanku sehingga aku membuatnya melakukan kewajibannya apabila Allah SWT menghendaki, patuhlah kepadaku selama aku taat kepada Allah SWT dan

\footnotetext{
' Untuk lebih detail lihat dalam penjelasan dalam al-Qur'an surat Asy-Syu'ara ayat 38 dan Ali Imran ayat I59
}

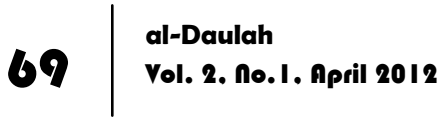


RasulNya, apabila aku tidak taat kepada Allah SWT dan Rasulnya, maka janganlah kalian semua mematuhiku“. ${ }^{2}$

Akan tetapi seiring perjalanan sejarah, jabatan khalifah yang sejatinya merupakan jabatan politis yang dipilih oleh masyarakat muslim berubah menjadi kekuasaan turun temurun yang ditradisikan pada zaman Dinasti Umayyah, Abbasyiyah serta kekuasaan kerajaan Islam setelahnya. Dengan semakin banyaknya kerajaan yang masing-masing memiliki kemandirian, maka timbullah karakteristik dan kereteria yang berlainan antara yang satu dengan yang lain dalam hal kepemimpinan sehingga dibutuhkan kembali rumusan yang sesuai didalam mendefinisikan hubungan antara kekuasaan Negara dan rakyat dalam system politik ketatanegaraan Islam.

Upaya tersebut telah dirintis oleh al-Mawardi sebagaimana yang termaktub dalam karya monumentalnya al-Ahkam alShultaniyah yang telah meletakkan dasar-dasar paradigma politik Islam yang dominan, akan tetapi pasca gerakan pembaharuan yang digelorakan oleh Jamaluddin al-Afghani dan terjadinya revolusi Iran, maka perdebatan tentang Islam dan demokrasi dalam bingkai nalar masyarakat Arab kembali menggelora terlebih lagi pasca kekalahan bangsa arab dalam peperangan melawan Israel yang terjadi pada bulan Juli 1967. Adalah Muhammad Abied al-Jabiri seorang pemikir garda depan Islam mencoba memformulasikan konsep politik kenegaraan Islam dalam bingkai nalar Arab, tulisan ini akan berupaya mendeskripsikan gagasan al-Jabiri khususnya yang tertuang dalam karyanya yang berjudul al-A'ql al-Siyasi-al-'Arabi:Muhaddidah watajalliyatuh, dalam kitab tersebut al-Jabiri berupaya menggugah rasionalisme kritis masyarakat Arab-Islam dalam bingkai nasionalisme kebangsaan dengan melakukan rekonstruksi atas rasionalisme kebudayaan Arab Islam dengan memberikan penyelarasan konsep politik Arab Islam tradisional yang bertumpu pada; al-Qobilah (Faktor

2 Dikutip oleh Abu A'la al-Maududi "Political Thought in Early Islam" dalam A History of Muslim Philosophy, ed. MM. Sharif, Vol. I (Wiesbaden: Otto Harrassonwitz, 1963) h. 662 
Kesukuan), al-Ghanimah (Ekonomi Tributair) dan al-Aqidah (idiologi primordial).

\section{Biografi singkat Muhammad Abed Al-Jabiri}

Muhammad al-Jabiri lahir di Figuig, sebelah selatan Maroko pada tahun 1936. dan pendidikannnya dimulai dari tingkat ibtidaiyah di madrasah Burrah Wataniyyah, yang merupakan sekolah agama swasta yang didirikan oleh oposisi kemerdekaan. Setelah itu ia melanjutkan pendidikannya di sekolah menenggah dari tahun 1951-1953 di Casablanca dan memperoleh Diploma Arabic high School setelah Maroko merdeka. Sejak awal al-Jabiri telah tekun mempelajari filsafat. Pendidikan filsafatnya di mulai tahun 1958 di univeristas Damaskus Syiria. Al-Jabiri tidak bertahan lama di universitas ini. Setahun kemudian dia berpindah ke universitas Rabat yang baru didirikan. Kemudian dia menyelesaikan program Masternya pada tahun 1967 dengan tesis Falsafah al-Tarikh Inda Ibn Khaldun, di bawah bimbingan N. Aziz Lahbabi (w.1992), dan gurunya juga seorang pemikir Arab Maghribi yang banyak terpengaruh oleh Bergson dan Sarter. ${ }^{3}$

Doktor bidang Filsafat, dia raih di Fakultas Sastra Universitas Muhammad V, Rabat (1970), dengan disertasi yang masih membahas seputar pemikiran Ibn Khaldun, khususnya tentang Fanatisme Arab. Desertasinya berbicara tentang "Fanatisme dan Negara: Elemen-Elemen Teoritik Khaldunian dalam Sejarah Islam" (Al-'Ashabiyyah wad Dawlah: Ma'âlim Nadzariyyah Khaldûiyyah fit Târikhil Islâmî). Disertasi tersebut kemudian dibukukan tahun 1971.

Jabiri muda merupakan seorang aktvis politik berideologi sosialis. Dia bergabung dengan partai Union Nationale des Forces Populaires (UNFP), yang kemudian berubah menjadi Union Sosialiste des Forces Populaires (UNSFP). Pada tahun 1975 dia menjadi anggota biro politik USFP. Di samping aktif dalam politik,

\footnotetext{
${ }^{3}$ Muhammed Abed al-Jabiri, Arab-Islamic Philosophy; A Contemporary Critique (diterjemahkan oleh Burhan dalam buku Kritik Pemikiran Islam; Wacana Baru Filsafat Islam), Yogyakarta, 2003 h. $v-x x$
}

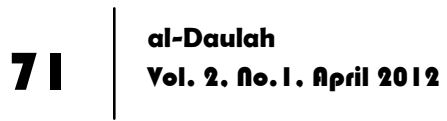


Jabiri juga banyak bergerak di bidang pendidikan. Dari tahun 1964 dia telah mengajar filsafat di Sekolah Menengah, dan secara aktif terlibat dalam program pendidikan nasional. Pada tahun 1966 dia bersama dengan Mustafa al-Qomari dan Ahmed Sattati menerbitkan dua buku teks, pertama tentang pemikiran Islam dan kedua mengenai filsafat, untuk mahasiswa S1.

Al-Jabiri telah menghasilkan berpuluh karya tulis, baik yang berupa artikel koran, majalah atau berbentuk buku. Topik yang selalu dicovernya juga bervariasi dari isu sosial dan politik hingga filsafat dan teologi. Karir intelektualnya seperti dimulai dengan penerbitan buku Nahwu wa al-Turast-nya, disusul dua tahun kemudian dengan al-Khitab al-'Arabi al-Mua'sir Dirasah Naqdiyyah Tahliyyah, kedua buku tersebut seperti sengaja dipersiapkan sedemikian rupa sebagai pengantar kepada grand proyek inteletualnya 'Naqd al-'Aql al-'Arabi (kritik akal Arab).

Buku 'Naqd al-'Aql al-'Arabi ini bertujuan sebagai upaya untuk membongkar formasi awal pemikiran Arab-Islam dan mempelajari langkah apa saja yang dapat diambil dari pemikiran Islam klasik tersebut. Untuk karya ini telah menerbitkan Takwim al-'Aql al'Arabi, Bunya al-'Aql-'Arabi, al-A'ql al-Siyasi-'Arabi, al-'Aql al-Akhlaqi al Arabiyyah, Dirasah Taahliliyah Naqdiyyah li Nuzum al-Qiyam fi alThaqafah al-Arabiyyah. Karya terpentingnya yang termasuk alTurath wa al Hadatshah, Ishkaliyyah al Fikr al-'Arabi al-Mua'asir, Tahafual al-thafut intisaran li ruh al-Ilmiyyah wa ta'sisan li akhlaqiyat al-Hiwar, Qadaya al-Fikr al 'Mu'asir Al'awlamah, Sira' al-Hadarat, alWahdah ila al-Ahklaq, al-Tasamuh, al-Dimaqratiyyah. Tahun 1996, alMashru al-Nahdawi al-'Arabi Muraja'ah naqdiyayh, al-Din wa al Dawlah wa Thabiq al-Shari'ah, Mas'alah al-Hawwiyah, al-Muthaqqafun fi al-Hadarah al-'Atabiyyah Mihnab ibn Hambal wa Nukkhah Ibn Rusyd, al-Tahmiyyah al-Basyaraiyyah di al-Watan al-'Arabi. ${ }^{4}$ 


\section{Konstruksi Epistimologis Nalar Politik kenegaraan Arab-Islam al-Jabiri}

Konstruksi nalar politik kenegaraan Arab-Islam Abed alJabiri merupakan bagian dari Ikhtiar dalam menyamakan persepsi masyarakat Arab minimal pada tingkat Pemikiran dan epistimologis sebelum sampai pada persatuan bangsa Arab (alWihdah al-Arabiyyah) pada tingkat empiris yaitu pada tataran sosiologis dan politis. ${ }^{5}$ Idiologi dan nalar politik kenegaraan ArabIslam dalam perspektif al- Jabiri ini berusaha diwujudkan tidak hanya saja pada tingkat sosiologis dan epistimilogis bangsa Arab saat ini, akan tetapi juga berusaha mentransformasikan kemajuan Arab-Islam pada masa lampau dalam tradisi atau turats, dimana ia akan mencari unsur-unsur kemajuan dalam upaya merekatkan dan mempersatukan aspek-aspek kebudayaan Arab yang terceraiberai sehingga memungkinkan untuk dijadikan pijakan idiologis kebangkitan "Nasionalisme Arab" ${ }^{6}$

Maka dalam konteks ini nalar politik Arab yang dimaksud Al-Jabiri dalam bukunya Al-'Aqlus Siyâsil 'Arabî: Muhaddidah wa Tajalliyatuh adalah "motif-motif (muhaddidât) tindakan politik (cara menjalankan kekuasaan dalam sebuah masyarakat), serta manifestasi (tajalliyât) teoritis dan praksisnya yang bersifat sosiologis". Dalam konteks ini al-Aql (nalar) merupakan motifmotif tindakan politik dan manifestasinya dalam realita praktis, semua tunduk dan dijalankan atas sebentuk logika internal yang mengorganisasi hubungan antar pelbagai unsurnya. Logika ini pada akhirnya berupa prinsip-prinsip yang dapat disifati dan dianalisis secara kongkrit. Sedangkan al-siyâsî (Politik) dalam konteks kajian ini bukanlah mereproduksi pengetahuan, akan tetapi menjalankan sebentuk kekuasaan, sebuah otoritas pemerintahan atau menjelaskan tata cara pelaksanaannya sehingga

\footnotetext{
${ }^{5}$ Abed al-jabiri, Wijhah Nazhr Nahw l'adah Bina Qodloyat al-Fikr al-Arabi al-Mu'ashir (Beirut : alMarkaz al-Tsaqofi al-Arabi, 1992) h. 225-240.

${ }^{6}$ Abed al-Jabiri, al-Aql al-Siyasi al-Arabi : Muhaddidah wa Tajalliyatuh (Beirut: Markaz Dirasah alWihdah al-Arabiyyah) 1992, h. 252.
} 
pada prinsipnya kajian ini mengulas tentang "nalar realitas Arab" ('al-aqlul wâqi'il 'al-arabî ), bukan nalar teoritik Arab sebagaimana yang dikaji dalam bukunya "Formasi Nalar Arab" (Takwîn al- 'Aql 'al-Arabî) dan "Struktur Nalar Arab" (Bunyat al- 'al-Aql al-'Arabî), dalam bahasa sederhana dapat dikatakan bahwa bahasan pada kajian ini mengacu pada bagaimana mengungkap motif-motif penyelenggaraan politik dan bentuk-bentuk manifestasinya dalam rentang sejarah panjang peradaban Arab-Islam sampai saat ini.

Dalam merumuskan konstruksi epistimologis nalar politik Arab-Islam tersebut, Al-Jabiri menggunakan beberapa perangkat konsep (al-jihâzul mafâhimi) yang terdiri dari dua sumber yaitu: Pertama, bersumber dari pemikiran ilmu sosial politik kontemporer; dan kedua, berasal dari sumber-sumber tradisi Arab-Islam sendiri. Al-Jabiri sangat memahami bahwa konsepkonsep yang dipinjam dari ilmu sosial-politik kontemporer yang notabene bersumber dari Barat mempunyai karakteristik serta keunikan-keunikan tersendiri yang tidak mungkin diterapkan secara utuh ketika mengkaji objek kajian yang berbeda (masyarakat Arab-Islam). Ikhtiyar mengungkap nalar politik mayarakat prakapitalis, negara peradaban Timur lama, masyarakat Arab dalam Abad Pertengahan dan Modern, yang biasa disebut "Dunia Ketiga" akan berbeda sekali dengan penelitian atas mayarakat kapitalis yang sudah maju.

Menyadari akan realitas tersebut, al-jabiri melakukan rekonstruksi epistemologis terhadap konsep-konsep yang dipinjam dari Barat. Misalnya konsep "bawah sadar politik" (allâ syu'ûrus siyâsî) yang diadopsi dari kajian Regis Debray (seorang profesor filsafat asal Perancis) yang menggunakan konsep tersebut untuk mengungkap bawah sadar politik masyarakat Barat. Dalam konsep bawah sadar politk Debray, fenomena politik tidak dibentuk oleh kesadaran manusia, gagasan-gagasan ataupun obsesi-obsesi mereka, dia juga tidak dibentuk oleh apa yang melandasi kesadaran itu sendiri, seperti relasi sosial ataupun kepentingan kelas. Akan tetapi penggerak utama dari sebuah 
fenomena politik adalah apa yang disebut sebagai "bawah sadar politik". Konsep bawah sadar politik ibarat struktur yang terdiri dari relasi-relasi materi yang bersifat kolektif serta memainkan peran yang bersifat koersif atas kesadaran individu-individu yang tidak dapat dibendung, dengan membentuk pola hubungan pada masyarakat suku dan beberapa pola hubungan sekterian yang sempit. Struktur hubungan yang terbentuk dari relasi yang tidak disadari ini akan selalu hidup, sekalipun suprastruktur masyarakat sudah mengalami perubahan sebagai bentuk respons atas perkembangan infrastruktur dalam masyarakat tersebut. Intinya, bentuk solidaritas kelompok dan fanatisme etnik dan obsesi mereka untuk mendapatkan keuntungan-keuntungan dan kepentingan-kepentingan akan selalu eksis baik secara laten maupun manifes dalam sebuah kelompok baik dalam masyarakat feodal, kapitalis maupun sosialis. ${ }^{7}$

Al-Jabiri tidak mengadopsi konsep Debray secara utuh, akan tetapi dia melakukan rekonstruksi epistimoligis terhadap konsepkonsep yang dapat diselaraskan dalam kebutuhan kultur masyarakat arab. Menurut al-Jabiri, Debray menerapkan konsepnya dalam masayarakat industrial Eropa, dimana hubungan sosial seperti relasi keluarga dan etnik menempati posisi di belakang hubungan ekonomi dan relasi produksi. Sementara dalam masyarakat Arab-Islam yang menjadi objek kajiannya adalah kenyataan yang merupakan kebalikan dari realitas yang ada pada mansyarakat barat. Hubungan sosial yang bersifat kekeluargaan dan etnik tersebut, dalam kehidupan politik masyarakat Arab, masih saja menempati posisi yang esensial dan faktual, sedangkan relasi ekonomi dan produksi tidak mendominasi masyarakat kecuali sebagian saja.

Oleh sebab itu al-jabiri mengambil posisi berbeda dari Debray yang berusaha mengungkap "apa yang bersifat keluarga dan agama dalam dunia politik Eropa kontemporer", sedangkan 
konsep bawah sadar politik yang digunakan al-Jabiri adalah untuk mengungkap "apa yang politis dalam perilaku atau tindak tanduk agama dan keluarga dalam masyarakat Arab dan Islam". Hal tersebut dirasa penting dikarnakan kehidupan politik dalam objek kajiannya pertama kali dilakukan berdasarkan pertimbangan agama dan kesukuan yang hal tersebut tetap dipertahankan sampai sekarang. Dengan demikian al-Jabiri menyimpulkan bahwa "bawah sadar politik yang menjadi pembentuk nalar politik Arab Islam tidak harus dicarikan dari tindakan-tindakan yang religius sektarian, akan tetapi harus mengungkap sisi politik yang menjadi lokomotif penggerak sektarianisme agama dan fanatisme kelompok dalam objek kajian merupakan faktor yang utama.

Dengan demikian dapat dikatakan bahwa Debray melakukan strukturisasi kajiannya dari "yang politik" menuju "yang ideologi" untuk sampai pada "yang agama", sedangkan al-Jabiri membaliknya dengan melakukan strukturisasi dalam konsep dari "yang sosiologis" membentuk "yang politik", yang politik kemudian membentuk ideologi, dan ideologi membentuk pola keagamaan, sebab dalam konteks masyarakat Arab, apa yang dipermukaan dianggap sebagai gejala sektarianisme agama, bukanlah merupakan pilihan politik, maka bawah sadar politik masyarakat Arab tidak selamanya dibentuk oleh agama sebagaiamana yang terjadi di Eropa akan tetapi justru sebaliknya sektarianisme agama yang menjadi topeng dan menyembunyikan bawah sadar politik. Dalam konteks tersebut al-Jabiri berusaha mencari apa yang berada dalam bawah sadar politik masyarakat Arab-Islam.

Dalam al-Aql-Siyasi al-Arabi: Muhaddidah wa Tajalliyatuh ini, al-Jabiri juga menggunakan konsep imajinasi sosial (imaginaire social atau al-mikhyâlul ijtimấ $i$ ) untuk mengkaji bawah sadar politik Arab-Islam. Konsep ini merupakan referensi utama bagi nalar politik Arab. Imajinsai sosial telah memberikan kerangka bagi alam bawah sadar politik Arab-Islam, dan menjelma menjadi 
semacam tanah air (mauthin) bagi jiwa atau sanubari tiap-tiap kelompok. Istilah imajinasi sosial ini juga dia pinjam dari ilmu sosial kontemporer. Dalam bahasa lain makna imajinasi sosial adalah "sekumpulan imajinasi yang memenuhi kepala bangsa Arab, baik dalam bentuk peristiwa-peristiwa, kisah kepahlawanan, ataupun pelbagai kegetiran yang mereka hadapi. Sekumpulan imajinasi itu dipersonifikasikan dalam sosok-sosok legendaris masa lampau bangsa Arab, seperti Imru'ul Qais, 'Amr ibn Maktum, Hatim Atthai', tragedi keluarga Amr bin Yaser, Umar bin Khattab, Khalid bin Walid, Umar bin Abdul Aziz, Harun AlRasiyid, Kisah 1001 Malam, Shalahuddin Al-Ayyubi, wali-wali yang saleh, Gamal Abdul Naser, dan yang lainnya, Khusus untuk imajinasi kalangan Syiah, tersebutlah nama-nama dan sosok keluarga Ali bin Abi Thalib sebagai titik sentralnya. ${ }^{8}$

Dari konsep tentang imajinasi sosial ini, al-Jabiri menegaskan bahwa nalar politik Arab merupakan sebuah konsep praksis dan ideologi, sebagai sebuah fenomena yang kolektif dari "imajinasi sosial" masyarakat itu sendiri, bukan dari struktur ilmu mereka. Maka dia mendefenisikan konsep "imajinasi sosial" sebagai "sejumlah pandangan, simbol-simbol, dilalah, norma-norma dan nilai-nilai yang memasok struktur bawah sadar politik masyarakat Arab dalam fase sejarah tertentu atau di kalangan komunitas masyarakat yang terorganisasi. Sebagai sebuah imajinasi kolektif, yang menjadi objek analisis bagi nalar politik adalah "soal keyakinan" (tidak peduli keyakinan itu benar atau salah, karena yang penting darinya hanya efektivitasnya untuk memobilisasi emosi massa).

Dua konsep yang telah terdiskripsikan diatas (bawah sadar politik dan imajinasi sosial), dijadikan oleh al-Jabiri sebagai konsep prosedural yang menghubungkan nalar politik Arab-Islam dengan morif-motif (muhaddidât) dan bagaimana manifestasinya (tajalliyât) dalam kenyataan. Motif-motif dan manifestasi politik ini, dalam

${ }^{8}$ Ibid, h. 265-270

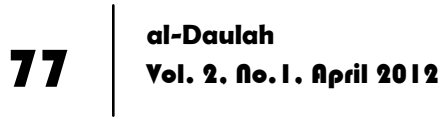


pandangan al-Jabiri merupakan sisi yang psikologis sekaligus sosiologis (jânib nafsî ijtimâ'i), unsur yang individual dan kolektif (al-'unshurus dzâtî wal jamâ'î) dari fenomena politik Arab Islam.

Sedangkan manifestasi dari konsep "domain politik" (almajâlus siyâŝ̂, political sphere) menurut al- jabiri dibedakan antara domain politik dalam masyarakat Eropa dengan domain politik dalam masyarakat Arab Islam, dia mencermati bahwa dalam masyarakat Eropa, domain politik tumbuh dan sangat kuat relasinya dengan berdirinya sistem kapitalis. Salah satu karakteristik sistem kapitalisme antara lain, diferensiasi dua hal dalam masyarakatnya yang sangat jelas : infrastruktur atau landasan ekonomi yang tulang pungungnya adalah insdustri, dan suprastruktur berupa perangkat negara, institusi, dan ideologi yang menjadi landasannya, sedangkan pada masyarakat yang belum sampai pada fase kapitalisme seperti masyarakat Arab Islam dan umumnya negara dunia Ketiga, perbedaan yang esensial antara dua struktur itu tidak begitu jelas dan bahkan biasanya kedua struktur itu saling tumpang-tindih seperti sebuah struktur yang menyatu. Maka sudah menjadi konsensus dalam ilmu sosial, bahwa masyarakat prakapitalis mempunyai spesifikasi tertentu yang di antaranya adalah :

Pertama adalah kesatuan antara infrastruktur dan suprastrukur masyarakatnya, atau paling tidak merupakan sebuah kesatuan yang rumit dalam artian hubungan antara unsurunsurnya saling berdialektika, saling mempengaruhi dan saling bertukar tempat. Kedua, kuatnya peranan kekerabatan dalam masyarakat prakapitalis, sehingga dari kuatnya peran kekerabatan tersebut, terkadang dilihat tidak hanya sebagai suprastruktur, tapi juga bagian dari infrastruktur masyarakat itu sendiri, dan menjadi kerangka hubungan produksi. Ketiga, kuatnya peran agama sebagai keyakinan dan merupakan bagian dari organisasi sosial yang memendam makna politis, baik secara eksplisit maupun implisit. Dalam masyarakat Eropa, agama dianggap "unsur yang terbungkam" (al-makbût), dan menjadi 
bagian dari bawah sadar politik. sehingga Debray dalam kajiannya berusaha mengungkap faktor yang terbungkam itu, sementara dalam masyarakat Arab-Islam, agama bukanlah bagian yang terbungkam, tapi justru menjadi sangat jelas, sehingga bawah sadar di balik kegiatan keagamaan itu harus diungkap agar menjadi jelas. ${ }^{9}$

Dari proses adopsi konsep yang telah direkonstruksi menjadi sebuah epismimologi yang melandasi nalar politik Arab Islam, alJabiri mengingikan agar dia dapat mendekati objek kajianya sebagai seorang mujtahid, bukan sebagai muqallid. Konsepkonsep yang digunakan tak lain hanya untuk lebih mendekatkan diri, mencerdaskan dan menghidupkan tradisi permikiran sosial Islam yang sudah pernah dirintis oleh Ibn Khaldun, sebab dalam pemikiran Islam, sosok Ibn Khaldun, khususnya dalam kajiannya tentang ilmu peradaban manusia (ilmul 'umrânil basyarî) telah berjasa mengungkap beberapa motif-motif di balik nalar politik sebuah peradaban manusia, tak terkecuali peradaban Islam. Hal itu paling tidak tergambar dari penegasannya tentang pentingnya perananan fanatisme (al-'ashabiyyah), faktor kekerabatan (alqarâbah), dan peranan dakwah keagamaan dalam formulasi sebuah negara dan kekuasaan.

Al-Jabiri juga berupaya melakukan analisis penyelarasan epistimoliogi terhadap perspektif masa kini masyarakat ArabIslam, untuk kembali menghadirkan beberapa konsep subtantif masa silam Islam yang setidaknya bertumpu pada penjelasan mendasar yang digunakan Ibnu Khaldun dalam menganalisis sejarah Arab-Islam. Diantara konsep subtantif tersebut adalah konsep fanatisme kelompok (al-'asyabiyyah al-qabiliyyah) dan dakwah keagamaan (al-da'wah al-dîniyyah), sedangkan konsep yang ketiga, yaitu fakor ekonomi, yang pada masa itu belum hadir sebagai faktor yang berdiri sendiri dan juga belum dianggap sebagai faktor determinan akan tetapi secara implisit Ibn Khaldun

${ }^{9}$ Ibid, h. 275

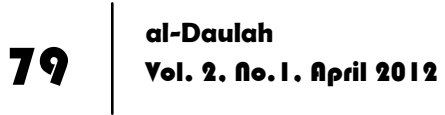


telah menyebut "cara produksi yang khas dalam masyarakat Arab" yaitu sistem perekonomian yang bergantung pada suasana peperangan, atau dengan cara menabung surplus produksi melalui kekuasaan yaitu kekuatan pemimpin, kepala suku, atau negara. Sistem ekonomi seperti inilah yang disebut Ibn Khaldun sebagai sumber mata pencarian (ekonomi) yang tidak wajar (madzhab fil ma'âsy ghairat thabî'i).

Berangkat dari tiga kunci yang dikemukakan Ibn Khaldun itu, al-Jabiri berupaya melakukan rekonstruksi konsep dalam terma yang agak berbeda demi menjelaskan nalar politik Arab-Islam. Lebih lanjut al-jabiri menggubah tiga konsep tersebut dengan istilah yang lebih fungsional dan akrab di telinga dan tradisi masyarakat Islam. Konsep Ibn Khaldun tentang pernanan dakwah keagamaan (al-da'wah al-diniyyah) dia ubah menjadi kategori akidah (al-'aqîdah), solidaritas kesukuan (al-'ashabiyyah al-qabiliyyah) dia singkat menjadi kategori kabilah (al-qabîlah atau suku), sementara untuk menjelaskan sistem ekonomi dia menggunakan nomenklatur fikih Islam, yaitu kategori ghanimah, harta rampasan perang (al-ghanîmah).

Dalam konteks ini konsep Kabilah yang dimaksud al-Jabiri adalah peran yang dapat dimainkan faktor kekerabatan (dalam perspektif antropologi modern), atau soal fanatisme ('ashabiyyah) sebagaimana yang telah disinggung Ibn Khaldun, Sedangkan yang dimaksud Ghanimah adalah peran yang dimainkan faktor ekonomi dalam sebuah masyarakat yang sistem ekonominya bergantung pada unsur kharaj (land tax atau pajak tanah), ${ }^{10}$ atau ri'i (revenue, income, atau pendapatan rutin), ${ }^{11}$ bukan atas dasar hubungan

\footnotetext{
${ }^{10}$ Menurut al-Jabiri kharaj dalam konteks ini tidak hanya apa yang dimaksudkan oleh para ahli fikih dari istilah itu, tapi mencakup semua yang ditarik oleh sebuah negara dalam komunitas Muslim, dari seorang Muslim ataupaun non Muslim, sebagai jibâyah atau pajak, (termasuk ghanimah, fai', jizyah, kharaj dan apa-apa yang ditetapkan sebagai pajak). Dengan kata laian kharaj melingkupi apa-apa yang ditetapkan oleh pihak yang menang atas yang kalah baik itu berbentuk upeti, ataupun pajak; baik yang berjangka ataupun selamanya. Yang dimaksud pihak yang menang itu bisa saja seorang emir, kabilah atau negara.

II Sedangkan Istilah Rî̀ di sini adalah pemasukan dalam bentuk uang ataupun barang yang dihasilkan oleh seseorang dari harta miliknya ataupun yang didapat dari emir secara teratur,
} 
produksi seperti patron-klien, feodalis (al-iqthâiy) dan hamba (alRaqabah), ataupun pemodal dan buruh. Yang dimakusud ghanimah ini juga tidak hanya terbatas pada sumber pendapatannya, tapi juga mencakup bagaimana cara menggunakannya (logika pendapatan berbeda dengan logika produksi). Jadi yang dimaksud ghanimah lebih lengkapnya adalah jenis pemasukan yang khusus, cara menggunakannya dan logika yang menyertainya.

Sementara itu yang dimaksud dengan Aqidah dalam konstruksi epistemologis Nalar politik Kenegaraan al-Jabiri adalah efektivitas sebuah doktrin itu sendiri dalam rangka mengukuhkan keyakinan atau kemazhaban. Akidah melingkupi sesuatu yang mampu menggerakkan suatu komunitas, sehingga menjadi semacam kabilah spiritual (qabîlah rûhiyyah), pertanda yang paling jelas dari akidah adalah beraninya orang menyabung nyawa untuk membelanya.

Tiga kategori itulah yang menjadi Kerangka epistimologis yang menjadi dasar nalar politik kenegaraan masyarakat Arab Islam yang digunakan al-Jabiri, ketiga hal tersdebut merupakan motif bawah sadar yang melandasi sebuah tindakan seorang individu, dia tidak berkaitan dengan data-data psikologis, tapi struktur simbol yang menempati imajinasi sosial suatu kelompok, bukan akal, atau pemahaman. Jadi, ketiganya dapat diibaratkan bawah sadar politik (imajinasi sosial) yang menggerakkan kegiatan politik sebuah kelompok atau individu-individu.

\section{Trilogi Nalar Politik Arab-Islam al- Jabiri ; Formulasi aplikatif dari al-Dakwah menuju al-Daulah}

\section{Formulasi Konsep al-Aqidah}

Dalam menkaji konsep al-aqidah, al-Jabiri berusaha mengungkap pelbagai gejala politik (al-madzharus siyâsî) dari

sehinnga dia dapat menggantungkan hidup dari pemasukan tersebut tanpa perlu melakukan kegiatan-kegiatan produksi. 
dakwah Nabi. ${ }^{12}$ Pembahasannya terfokus pada segala aksi dan reaksi yang memiliki kandungan politis dan berperan dalam membentuk imajinasi sosial-politik komunitas muslim pertama di satu sisi, dan menggerakkan reaksi musuhmusuhnya (elit Quraisy) di sisi lain. Beberapa riwayat menyebutkan bahwa sebelum Nabi menjadi seorang yang sukses menggalang massa untuk mendukung dakwahnya, di kalangan elit Quraisy sudah muncul desas-desus bahwa Nabi akan menjadi seorang penguasa yang akan menaklukkan kekaisaran Romawi maupun Parsi.

Akan tetapi menurut al-Jabiri, meskipun tidak ada referensi yang falid untuk mendukung asumsi bahwa dakwah Nabi bermuatan politik tertentu, akan tetapi dia tetap melakukan pembacaan politik (qirâ'ah siyâsiyyah) terhadap kiprah Nabi dalam batas-batas tertentu. Karena sangat jelas terlihat bahwa penentang utama dakwah Nabi Muhammad adalah dari kalangan elit Quraisy yang sejak awal telah beranggapan bahwa dakwah rasulullah Muhammad SAW merupakan proyek politik.

Pesan yang mereka tangkap dari dakwah yang dilakukan Nabi adalah, meruntuhkan hegemoni sosial, ekonomi dan politik yang selama ini mereka kuasai, sehingga dalam pandangan al-Jabiri, dalam menghadapi siasat para elit Quraisy Mekkah tersebut, tidak mungkin dakwah Nabi mengambil posisi yang pasif, akan tetapi tentu juga memperhatikan aspek-aspek politis untuk merealisasikan dakwahnya agar sukses. Berdasarkan asumsi tersebut al-Jabiri berusaha mengkaji dan mengungkap aspek politik dari dakwah yang dilakukan oleh Rasulullah SAW dengan meletakkan garis demarkasi dalam posisi biner antara dakwah

2 Dalam kajian ini coba bandingkan dengan hasil penelitian Dr. Muhammad Rawas Qal'ah Je, Qirâah Siyâsiyyah Lis Sîrah an-Nabawiyyah. Lebanon: Darun Nafais, 1996. 
nabi dan rintangan yang dilakukan oleh kaum quraisy pada sisi yang lain. ${ }^{13}$

Al-Jabiri membagi dakwah Nabi pada periode Mekkah ke dalam dua fase. Pertama, fase dakwah gerilya (sirran) dan kedua dakwah terang-terangan (jahran). Peran akidah dalam membentuk nalar politik komunitas muslim pertama yang oleh al-Jabiri disebut sebagai "komunitas spiritual" (jamâ'ah rûhiyyah) sangat terlihat dalam fase dakwah pertama ini. alJabiri mencermati bahwa ikatan solidaritas yang paling dominan dalam mengikat generasi Muslim pertama tak lain adalah unsur akidah: keimanan pada Allah SWT, Nabi dan wahyu. Sementara peran kabilah dan ghanimah belum terlihat pada mereka, dan justru sangat menonjol pada kubu elit Quraisy yang dalam hal ini merupakan penghalang utama dari perjuangan Rasulullah, sehingga pertarungan politik pada masa itu dapat dikatakan sebagai pertarungan antara kategori akidah melawan qabilah dan ghanimah. ${ }^{14}$

Di dalam fase dakwah gerilya (Sirri) yang berjalan lebih dari tiga tahun, ayat-ayat yang turun sebagai konsep akidah masih sangat jauh dari kesan konfrontasi atas elit Quraisy, Rasulullah SAW mengambil strategi yang menjauh dari konfrontasi dengan kaumnya tersebut, sehingga dia tidak dapat merebut hati orang Mekkah untuk mengamini dan mengimani dakwah yang dilakukannya. Di antara sedikit orang yang berhasil direbut hatinya antara lain adalah Khadijah binti Khuwailid (seorang saudagar kaya yang pada akhirnya menjadi isteri Nabi), Ali bin Abi Thalib (waktu itu berusia 10 tahun, dan merupakan sepupu Nabi), Zaid bin Haritsah (budak kecil yang diberikan kepada Khadijah dan lalu dibebaskannya), Abu Bakr bin Qahafah (38 tahun, dari

\footnotetext{
13 Nalar berfikir semacam ini timbul dari kesadaran kritis untuk mengungkap sesuatu yang tersembunyi sehingga dapat dipahami motifnya, lihat dalam Muhammad Abed al-Jabiri, al-Khitab al-Arabi al-Mu'ashir: Dirasah Tahliliyah Naqdiyah (Beirut: Markaz Dirasah al-Wihdah alArabiyyah, 1992)

${ }^{14}$ Op. Cit. Al-Aql al-Siyasi al-Arabi, h. 282
}

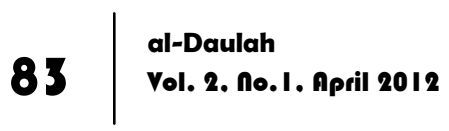


kabilah kecil, Thaim), Utsman bin Affan (34 tahun, dari kabilah terkuat Quraisy Bani Umayyah), Zubeir bin Awwam (seumur Ali, dari bani Asad, anak bibi Nabi), Abdurrahman bin 'Auf (30 tahun) dan Sa'ad bin Abi Waqash (seumur Ali, dari Bani Zuhrah), Thalhah bin 'Ubaidillah (sebaya Ali, dari kabilah Taim sebagaimana Abu Bakr). Ditambah dengan Amar bin Yaser, Shuhaib bin Sinan, Bilal bin Rabah al-Habasyi (dari kalangan budak), nama-nama tersebut merupakan generasi paling awal dalam memeluk Islam yang dikarenakan sematamata karena unsur akidah tanpa ada pengaruh atau perimbangan lain baik yang terkategori sebagai kabilah ataupun ghanimah. ${ }^{15}$ Kandungan politis dari dakwah Nabi pada fase pertama ini dapat dicermati dari ayat-ayat Qur'an yang membuat marah kaum Quraisy, karena menegaskan bahwa kaum pagan dan kafir akan mendapat sanksi dunia dan akhirat, bukan hanya karena kekufuran dan paganisme yang mereka anut, tapi juga disebabkan penguasaan mereka atas sumber-sumber kekayaan, dan ketidakpedulian atas kaum fakir miskin.

Pada fase kedua dakwah periode Makkah (fase terangterangan), yang berlanjut dari tahun keempat kenabian sampai tahun ke tigabelas, mulai terjadi konfrontasi langsung pada level akidah antara generasi awal Islam dengan elit Quraisy. Pada fase ini, ayat-ayat Al-Qur'an yang turun sudah mulai melakukan kecaman-kecaman dan secara eksplisit bertentangan dengan kepercayaan dan kepentingan kaum Quraisy. Fase ini disebut oleh al-Jabiri sebagai fase dakwah terang-terangan dan konfrontasi atas berhala-berhala kaum kafir Mekkah. Pada fase ini juga reaksi Quraisy semakin keras, dari bentuk ejekan dan caci maki sampai pada penyiksaan jasmani. Sosok-sosok seperti Abu Lahab (paman Nabi sendiri), dan isterinya Ummu Jamil (saudara Abu Sufyan) selit-elit serta

15 Ibid, h. 285. 
pembesar Quraisy yang lain seperti Walid bin Mughirah mulai tampil sebagai sosok-sosok yang memberikan tanggapan yang keras terhadap dakwah Nabi. ${ }^{16}$

Dalam sebuah riwayat dijelaskan Walid bin Mughirah pernah merasa iri pada Nabi Muhammad, dia lantas berkata, “Mengapa pula Al-Qur'an diturunkan kepada Muhammad, dan mengacuhkan aku sebagai pembesar Mekkah dan Urwah bin Mas'ud pembesar Thaif." 17 Pada masa inilah dimulai penyiksaan terhadap komunitas Muslim pertama, khususnya kaum lemah (tidak mendapatkan proteksi kabilah atau kaum pendatang) sepeti Ammar bin Yaser dan Bilal bin Rabah. Tekanan-tekanan ekonomi juga dilangsungkan untuk melakukan gangguan psikologis atas generasi awal Islam, sehingga beberapa kalangan Islam yang lemah terpaksa melakukan beberapa kali eksodus terutama ke Habasyah dan Thaif.

\section{Formulasi Konsep al-Qabilah}

Dalam formulasi konsep al-qabilah ini, al-Jabiri menerangkan bagaimana peran unsur kekerabatan baik bersifat positif maupun negatif dalam perilaku politik atau memainkan otoritas kelompok yang dirasakan atau dimanfaatkan oleh Nabi, sejak awal mula dakwah hingga terbentuknya negara Madinah. Domain kabilah ini terbatas pada suku-suku Quraisy di Mekkah, dan interaksi mereka dengan beberapa kelompok di Madinah. Efektivitas unsur akidah bersifat alamiah belaka, tapi digerakkan oleh unsur kekerabatan atau loyalitas, aliansi ataupun kedekatan jarak antar individu. Sebagaimana dimaklumi, dalam masyarakat kabilah, berlaku hukum perseteruan antarkabilah (qânûn shirâ'il qabilî).

${ }^{16}$ lbid, h. 287-290.

17 Lihat dalam Tosihiko Itsuzu, Relasi Tuhan dan Manusia dalam semantika al-Qur'an (PT. Rosda Karya: Bandung, 1992) 
Dalam sistem kabilah, berlaku prinsip yang menunjukkan solidaritas kesukuan, seperti ungkapan yang selama ini sering kita dengar dalam slogaan ashabiyah orang arab "anâ wa akhî 'alâ ibn 'ammî, wa anâ wa ibn 'ammî alal gharîb" (aku dan saudaraku berpihak pada anak pamanku dan aku besarta anak pamanku berpihak pada yang "bermusuhan" dengan orang asing). ${ }^{18}$

Pada periode Mekkah, kabilah Quraisy merupakan kabilah yang paling kuat. Kata Quraisy sendiri merupakan penamaan untuk sekumpulan kabilah-kabilah yang dinisbatkan langsung ke sosok Fahr yang merupakan nenek moyang suku-suku Arab Mekkah yang telah mendiami Mekkah sejak awal. Konfigurasi suku-suku yang menghuni Mekkah ketika itu akan menunjukkan secara jelas bagaimana peran kesukuan dalam masyarakat Mekkah. Sebagaimana diterangkan Karena Armstong, di dalam etika masyarakat suku, individualitas melebur di dalam kolektivitas suku. Solidaritas suku amat kuat dan bersifat koersif dalam menggerakkan emosi individu-individu. Perseteruan antarsuku merupakan hal biasa terjadi, dan hanya dapat diredam oleh mekanisme vendetta (al-tsa'r). Pendek kata, betapapun buruknya persepsi tentang vendetta, dia merupakan salah satu mekanisme untuk bertahan hidup dalam komunitas kesukuan. ${ }^{19}$

Setidaknya ada dua belas suku yang mendiami Mekkah masa dakwah Nabi di Mekkah. Mereka hidup di Mekah tanpa otoritas yang tersentralisasi. Untuk mengatasi berbagai persoalan yang terjadi maka salah seorang diantara mereka yang bernama Quraisy (kakek keempat Nabi) mendirikan "pusat perundingan" (dârun nadwah). Dalam masyarakat kabilah, juga sudah dikenal aliansi-aliansi antarsuku untuk

${ }^{18}$ Op. Cit. Al-Aql Siyasi al-Arabi, h. 292.

${ }^{19}$ Karen Armstrong, Muhammad Sang Nabi: Sebuah Biografi Kritis. Terj. Sirikit Syah. Surabaya: Risalah Gusti, cetakan III, 200I, h. 62. 
saling membantu. Aliansi itulah yang memberikan semacam proteksi kepada tiap-tiap individu dalam sebuah kabilah agar tidak diperlakukan secara semena-mena oleh kabilah lainnya.

Sebab dalam hal ini berlaku prisip menyentuh salah seorang individu dalam sebuah kabilah akan berakibat pada reaksi seluruh anggota kabilah, dan potensial menyulut perang saudara. Pola hidup kesukuan seperti ini, sedikit banyak bersifat positif untuk keselamatan Nabi dan beberapa pengikutnya. Mereka yang merupakan anggota keluarga salah satu kabilah Quraisy tidak akan diperlakukan secara semenamena. Paling tidak, ini terlihat dari peran Abu Thalib, paman Nabi yang gigih dalam memproteksi Nabi dari ancamanancaman penentangnya. Proteksi relatif atas Nabi dari kabilahnya ini agak kontras dengan para muslim dari kaum yang tidak punya tulang punggung dari kabilahnya sendiri, seperti Ammar, Bilal, dan Shuhaib, sedangkan Nabi mendapatkan perlindungan dari kerabatnya (Bani Hasyim dan Bani Muthallib) sekalipun mereka tidak turut serta mengamini dakwahnya. ${ }^{20}$

Kuatnya peran positif kabilah dalam dakwah Nabi juga dapat dicermati dari dua peristiwa penting keislaman Hamzah paman Nabi dan Umar bin Khattab. Hamzah masuk Islam secara tidak sengaja, dalam rangka menggertak kabilah yang mengejek dan menyakiti Nabi. Ketika itu, tersiar kabar bahwa Abu Jahl (klan Makhzum) mengejek dan mencerca Nabi kala berpapasan di bukit Shaffa. Berita itu sampai ke telinga Hamzah dari mulut sorang budak Abdullah ibn Jad'an (bani Taim, sekutu Bani Hasyim). Seketika itu juga Hamzah naik pitam dan mencari batang hidung Abu Jahal. Ketika berjumpa dia mengatakan, "Berani sekali Engkau mencercanya, sementara aku sudah menganut agamanya (padahal dia belum menganut Islam ketika itu), dan aku mengatakan apa yang dia

${ }^{20}$ Lihat Philip K. Hitti; History of The Arabs, (Palgrave Macmillan, Edisi Revisi kel 0, New York), 2002.

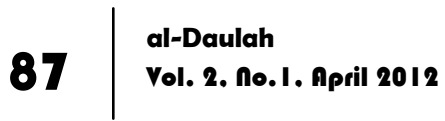


katakan. Berikan padaku reaksi yang serupa kalau kau memang benar jantan!" Ketika itu, beberapa orang dekat Abu Jahal bereaksi untuk membela Abu Jahal, tapi mereka dilarang Abu Jahal, kuatir terjadi pertempuran berdarah antar kabilah yang potensial untuk tidak berkesudahan..$^{21}$

Kisah keislaman Umar juga memberikan indikasi kuat tentang peran dominan kabilah dalam masyarkat Arab dan pengaruhnya terhadap dakwah Nabi. Suatu ketika Umar sudah siap menghunuskan pedangnya untuk membunuh Nabi yang dia sebut sebagai "seorang Shabean yang telah memecahbelah harmoni Quraisy". Dalam perjalanan menuju Nabi, dia diingatkan oleh Na'im bin Abdullah bahwa Bani Abdi Manaf (bukan hanya bani Hasyim) tidak akan membiarkan Umar hidup bebas tanpa membuat perhitungan atas kematian Muhammad. Umar akhirnya mengurungkan niatnya dan justru masuk Islam setelah tersentuh secara spiritual oleh makna Al-Qur'an dalam surat Thaha.

Dari berbagai deskripsi historis tersebut, al-Jabiri berkesimpulan bahwa hubungan kesukuan yang sangat rumit itu tidak memungkinkan suku Quraisy untuk membersihkan aktivis-aktivis dakwah yang berada bersama Nabi. Maknanya, dakwah Nabi dapat tetap berlangsung dalam naungan solidaritas kerabat dalam sistem kabilah, bahkan, hubungan dengan Madinah, terutama dengan kabilah Aus dan Khazraj juga tidak lepas dari soal perimbangan kekuatan kabilah setelah Nabi merasa tidak lagi mempunyai kekuatan yang memadai sebagai penopang dakwahnya di Mekkah. Akan tetapi yang menarik adalah setelah pindah ke Madinah, Nabi relatif berhasil mengembangkan sistem persaudaraan lintas kabilah antara komunitas Muslim pertama (kaum Muhajirin dan Anshor), dan kaum Muslim dengan kabilah-kabilah 
Yahudi di Mekkah melalui Piagam Madinah (mitsâqul madînah).

Dengan demikian pada periode Madinah, Nabi cukup berhasil mengantikan solidaritas kesukuan menjadi solidaritas lain yang bersiafat ideologis, yaitu solidaritas ummah atau millah. Bahkan, Nabi berhasil membentuk semacam "pakta pertahanan bersama" antara kaum muslim dengan Yahudi, untuk sama-sama memproteksi wilayah Madinah dari kemungkinan serangan Quraisy Mekkah. ${ }^{22}$

Akan tetapi, di samping peran-peran positif tersebut, kabilah juga punya beberapa peran negatif diantaranya kesulitan Nabi menembus proteksi kabilah terhadap individuindividu dalam kelompok kesukuan tersebut untuk menganut Islam termasuk di antara peran negatif kabilah. Hal itu disebabkan karena individu-individu dalam sebuah kabilah bukanlah sosok-sosok yang otonom atau independen dari komunitasnya. Pilihan untuk mengambil arus yang berlawanan dan berbeda dari prinsip umum kabilah merupakan tindak bunuh diri (asybah bil intihhâr). Di sinilah rahasia mengapa dakwah Islam kemudian harus melakukan terobosan-terobosan dan penaklukan-penaklukan terhadap sistem kabilah yang menjadi tembok penghadang sesungguhnya. Tapi persoalan kabilah saja tidak cukup menjadi motif mengapa mereka sulit menerima dan ditembus. Lebih esensial dari sekedar kabilah adalah persoalan Ghanimah atau sumber-sumber ekonomi yang perlu dipertahankan.

\section{Formulasi Konsep al-Ghanimah}

Suatu saat seorang penguasa Bani Umayyah bernama Abdul Malik bin Marwan bertanya kepada Urwah bin Zubeir tentang mengapa kaum Quraisy menentang dakwah Nabi.

22 Ibid, h. 174.

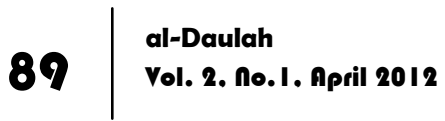


Urwah menjawab, "Ketika Nabi menyeru kaumnya dengan petunjuk dan pencerahan yang diturunkan kepadanya, mereka mulanya tidak menjauh, dan nyaris akan menanggapinya. Sampai kemudian Nabi menyebut-nyebut berhala mereka, hingga datangnya sekelompok orang berharta melimpah yang kemudian mengingatkan mereka akan bahaya dakwah tersebut. Sejak saat itulah mereka menghindar dari Nabi, kecuali sedikit yang dijaga oleh Allah". Di sini, sebenarnya terlihat sekali kontras luar biasa antara keyakinan (celaan terhadap berhala-berhala mereka) dengan kedatangan orang kaya yang umumnya tak lebih penting bagi mereka kecuali keselamatan harta benda mereka. ${ }^{23}$

Menurut al-Jabiri dan beberapa kajian tentang keyakinan Quraisy di masa Nabi, berhala-berhala bagi kaum Quraisy tidak sampai derajat "yang sakral" sehingga seseorang rela mati untuk mempertahankan kesakralannya. ${ }^{24}$ Berhalaberhala tersebut tak lebih dari simbol untuk menjaga sumber pendapatan dan tulang punggung ekonomi mereka. Mekkah merupakan sentra berhala masing-masing kabilah, tempat mereka berkumpul dalam ritual haji yang banyak mendatangkan devisa bagi suku-suku Quraisy. Rasionalisasi kekhawatiran mereka akan berhala tersebut tak lebih karena itu sama artinya dengan bertindak lancang atas sumber pendapatan dalam haji dan aktivitas ekonomi yang berkaitan denganya. Kekhawatiran akan kehilangan sumber-sumber pendapatan mereka membuat Quraisy dengan keras menentang dakwah Nabi.

${ }^{23}$ Op.cit, al-Aql al-Siyasi al-Arabi.

${ }^{24}$ Al-Jabiri antara lain memberi alasan, misalnya, di Mekkah tidak terdapat kaum agamawan yang mengurusi secara khusus persoalan agama. Sementara itu, nama-nama Tuhan mereka, seperti Latta, Uzza, dan Manât, yang biasa disebut sebagai "anak perempuan tuhan" lebih berisifat hinaan daripada sakralisasi. Sebab, maklum bahwa kultur Arab ketika itu sangat tidak menyukai anak perempuan. Bagaimana mungkin mereka memberi nama "tuhan" mereka dengan namanama perempuan dan menyebutnya "anak-anak perempuan tuhan 
Al-Jabiri berpandangan bahwa perpindahan Nabi dari Mekkah ke Madinah juga dapat dibaca sebagai proses menjalankan dakwah dengan cara yang lain, seperti megutus ekspedisi dan menyerang kafilah dagang Quraisy, bukan semata-mata karena takut dan melarikan diri dari kejaran Quraisy. Cara-cara berdakwah seperti itu, ketika itu "dapat dibenarkan" sebagai bentuk "embargo" ekonomi atas Mekkah, demi menanti penyerahan total secara politis agar mereka selanjutnya memeluk Islam.

Dari penjelasan ini dapat di katakan bahwa pemikiranpemikiran tentang ghanimah sudah muncul dalam nalar politik Islam generasi awal. Kenyataan itu pulalah yang sudah dideteksi secara jeli dan cermat oleh Nabi sehingga Beberapa serangan Nabi atas kafilah Quraisy, misalnya yang terjadi di Buwath, dan beberapa perang seperti Perang Badar dan yang lainnya tak lain untuk memberikan pukulan ekonomis terhadap kaum Quraisy. Kepentingan inilah yang dapat dipahami dari penentangan Quraisy terhadap ayat-ayat Qur'an. Dalam pengertian lain menyentuh persoalan berhala mereka, dalam pemahaman Quraisy tak lain adalah pengumuman perang terhadap sumber-sumber ekonomi mereka.

Dari perspektif ghaniman ini, al-Jabiri menyatakan bahwa ghanimah pada awalnya bukanlah tujuan utama Nabi. Hanya saja, pukulan-pukulan terhadap kepentingan ekonomi Quraisy perlu dilancarkan demi menaklukkan mereka, sembari menegaskan bahwa hanya dengan Islam mereka akan dapat diuntungkan. Islamnya kaum Quraisy sangat berarti untuk mengislamkan suku-suku lain, karena mereka adalah suku yang berkuasa di Mekkah, sehingga proses penghadangan terhadap ekspedisi perniagaan Quraisy perlu dilancarkan dari Madinah, sebab jalur perdagangan antara Mekkah dan Syam (Syiria sekarang) akan melewati jalur Madinah. Dalam konteks ini Nabi sangat memahami bahwa strategi perang yang paling 
menyakitkan bagi Quraisy adalah yang dapat menyadarkan bahwa kepentingan niaga mereka akan benar-benar terancam.

Beberapa perang, seperti perang Badr benar-benar telah memberikan harta rampasan perang yang memadai bagi kaum Muslim di Madinah. Ketika itu pulalah, kekuatan Abu Jahal dan sukunya bani Makhzum benar-benar luluh lantak, dan Bani Umayyah kemudian menguasai Mekkah secara penuh. Setelah perang Badr dan banyaknya harta rampasan perang, turun surat Al-Anfal yang memberikan tuntunan teknis distribusi jatah ghanimah, yaitu $4 / 5$ untuk yang ikut berperang, dan 1/5 untuk Allah dan Rasulnya. Sejak saat itu, persoalan ghanimah sudah menjadi bagian penting dari "bibit negara Madinah", bahkan, bagi kalangan Muslim baru, menjadi salah satu stimulan untuk masuk ke dalam pangkuan Islam. Al-Jabiri juga menyebutkan sebanyak 17 ghazwah dan sirriyyah yang dilancarkan Nabi terhadap suku-suku badui sekitar Mekkah dan Madinah, dilancarkan untuk "memberi pelajaran" kepada mereka agar mau memeluk Islam, menambah wibawa Islam, atau untuk menjamin keamanan jalur perdagangan Islam dari Madinah ke Syam. ${ }^{25}$

Akan tetapi persoalan ghanimah selain berperan positif juga mempunyai dampak-dampak negatif terhadap perkembangan Islam selanjutnya. Al-Jabiri menyebutkan, banyaknya ghanimah yang dihasilkan dalam beberapa penaklukan, dan berduyun-duyunnya orang memeluk Islam tidak dapat mengiring mereka untuk melampaui derajat "Islam politis-perang" menuju Islam pada level akidah dan keimanan. Sisi-sisi negatif dari faktor ghanimah ini akan ikut andil dalam perpecahan kaum generasi Muslim awal, bahkan sejak Nabi masih hidup. Cerita tentang ghanimah Hunain menjadi bukti faktual akan hal ini. 
Sebelumnya, perang Uhud juga menjadi bukti bahwa faktor ghanimah selain merupakan faktor kekuatan, juga menjadi kelemahan di kemudian hari. Sisi-sisi negatif aspek

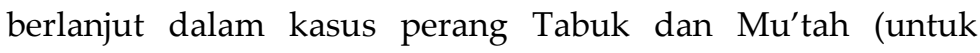
melawan Imperium Romawi), dan bagaimana tanggapan kaum Muslim awal dalam peristiwa tersebut. Ketika Nabi mempersiapkan diri untuk berperang, banyak dari kaum Muslim baru yang derajat keislamannya masih pada level loyalitas politik, enggan ikut perperang. Surat At-Taubah yang turun setahun menjelang wafatnya Nabi, menjadi bukti sejarah dan nyaris seperti laporan kritis tentang kondisi internal negara dakwah Nabi.

Pada tahun kesepuluh Hijriah, menjelang wafatnya Nabi, semua kabilah di Jazirah Arab sudah tunduk dan loyal kepada kepemimpinan politik Nabi, akan tetapi Nabi juga telah mengutus dan menempatkan wakil-wakilnya di tiap-tiap wilayah sebagai dutanya. Akan tetapi dapat dikatakan bahwa Islamnya beberapa kabilah di Jazirah Arab - seperti islamnya kaum A'râb, kaum munafik Madinah, dan kaum Quraisy ketika penaklukan Mekkah dan suku Tsaqif - semuanya dapat dikatakan sebagai bentuk Islam politis daripada Islam ideologis. Salah satu pertanda loyalitas kepada suku yang menang (Nabi di Madinah) adalah dengan cara memberikan upeti secara rutin, tidak beraliansi dengan musuh, dan tidak menunjukkan permusuhan nyata. Hanya saja, sebagaimana biasanya, loyalitas itu akan berhenti dengan matinya sang pemimpin/penakluk. Inilah yang terjadi kemudian dengan negara dakwah Nabi. Demi mendengar sakitnya Nabi, beberapa kabilah tersebut bergegas murtad lagi (membelot dari Islam), para dukun dimasing-masing suku kemudian memproklamirkan diri sebagai nabi baru, dan beberapa kepala suku melakukan pemberontakan.

Akn tetapi yang menarik adalah kebanyakan kabilah yang membelot dari "kekuasan sentral" tersebut tidak termasuk dua 
kabilah besar yaitu Quraisy dan Tsaqib, dua kabilah yang dulunya menjadi musuh utama rasulullah SAW ketika merintis dakwahnya, hal ini disebabkan, kekuasaan di pusat telah berjalan mengarah pada prakondisi menuju negara Quraisy sejati.26

\section{Ikhtitam}

Paparan al-Jabiri yang cukup mendetil tentang nalar politik Islam dalam kajian ini merupakan upaya pembacaan ke belakang atas bentuk nalar politik yang telah terpatri dalam pemikiran politik Islam dengan menggunakan tiga prinsip utama yaitu akidah, kabilah dan ghanimah. Bagi al-Jabiri, pembacaan ulang itu perlu dilakukan sebagai bagian dari pelacakan mendasar ( $t a^{\prime}$ shîlul ushîl) atas fenomena historis Islam sebagai bagian yang sangat berpengaruh terhadap perkembangan pemikiran Islam saat ini.

Menurut pendapat al-Jabiri, pada hakekatnya perbincangan tentang nalar politik Islam masih belum bermula. Kitab al-Agl al-Siyasi al-Arabi : Muhaddidat wa Tajalliyatuh ini, tak lain merupakan bagian dari aktualisasi dan Ikhtiyar akademik sebagai perbincangan tentang nalar politik Islam di antara bentuk-bentuk lain yang telah ada.

Dalam kajian dalam kitab al-aql al-Siyasi ini, al-Jabiri telah meletakkan eleman-eleman mendasar dan kerangka berpikir teoritis untuk memudahkan pengungkapan lebih lanjut tentang nalar politik Islam. Sejumlah kemungkinan analisis tentang nalar politik Arab-Islam masih terbuka untuk dikembangkan. Al-Jabiri menggunakan pendekatan fungsional untuk menerapkan konsep-konsepnya dalam

${ }^{26}$ Untuk lebih memperjelas tentang bagaimana detilnya kekuasaan Islam berpindah ke tangan Quraisy, lihat buku Khalil Abdul Karim, Quraisy: Minal Qabilah ilad Daulah Al-Markaziyyah. Buku ini sudah diterbitkan edisi Indonesianya oleh Penerbit LKiS dengan judul Hegemoni Quraisy. 
menelaah secara kritis beberapa contoh kemungkinan praktek politik Islam dalam kurun panjang sejarah Islam.

Akan tetapi konsep pendasaran saja tidak cukup dalam melakukan analisis atas fenomena politik Islam mutakhir. Dan hal tersebut diakui al-Jabiri sendiri. Pengakuan atas sistem konstitusi yang demokratis misalnya, memang membuka jalan bagi modernisasi politik dunia Arab dan Islam, akan tetapi hal itu saja tidak cukup, karena Nalar politik tidak hanya ditentukan oleh bentuk pemerintahan dan butir-butir konstitusi yang mengaturnya. Tapi semua itu selalu saja tunduk pada beberapa penjelasan sosiologis, ekonomi, dan kebudayaan, sehingga dalam rekomendasi al-Jabiri, pembaruan beberapa kunci penjelasan yang dia gunakan (akidah, kabilah dan ghanimah) tadi, mutlak diperlukan untuk memenuhi tuntutan kebangkitan dan kemajuan dunia modern.

Akan tetapi persoalanya adalah pembaruan pada level penjelasan tadi saja tidak bisa berlangsung kecuali dengan melakukan negasi sejarah yang buruk, dengan memberi kerangka analisis yang kontemporer. Di sinilah letak pentingnya kritik masa kini dan masa silam dalam pandangan al-Jabiri. Masa lampau dan masa kini belum terlepas betul dari ingatan atau imajinasi masyarakat Islam.

Dengan demikian kritik harus diajukan atas keduanya yaitu atas fondasi dasar yang membentuk kesadaran politik kita atau kritik pada bawah sadar nalar politik itu sendiri. Pemikiran politik Islam tidak mengenal kecuali bentuk-bentuk mitologisasi pemimpin dan ideologi kekuasaan. Ahli Sunnah telah melakukan kritik yang keras terhadap yang pertama, tapi belum melakukan kritik yang memadai terhadap ideologi kekuasaan negara. dengan demikian kritik nalar politik Arab dan Islam harus dimulai dari dua hal sekaligus yaitu kritik atas mitologisasi pemimpin dan penolakan terhadap status quo. 


\section{Daftar Pustaka}

Ali Abdul Raziq, Al-Islâm Wa Ushûlul Hukm, Kairo: Darul Hilal, 2000.

Abu A'la al-Maududi "Political Thought in Early Islam" dalam A History of Muslim Philosophy, ed. MM. Sharif, Vol. 1 (Wiesbaden: Otto Harrassonwitz, 1963).

Karen Armstrong, Muhammad Sang Nabi: Sebuah Biografi Kritis. Terj. Sirikit Syah, (Surabaya: Risalah Gusti, cetakan III), 2001.

Muhammad Abed al-Jabiri, al-Khitab al-Arabi al-Mu'ashir : Dirasah Tahliliyah Naqdiyah (Beirut: Markaz Dirasah al-Wihdah alArabiyyah), 1992.

Philip K. Hitti ; History of The Arabs, (Palgrave Macmillan, Edisi Revisi ke10, New York), 2002.

Muhammad Rawas Qal'ah Je, Qirâah Siyâsiyyah Lis Sîrah anNabawiyyah, (Lebanon: Darun Nafais), 1996.

Tosihiko Itsuzu, Relasi Tuhan dan Manusia dalam semantika alQur'an, (PT. Rosda Karya: Bandung), 1992.

Muhammad Abed al-Jabiri, Wijhah Nazhr Nahw I'adah Bina Qodloyat al-Fikr al-Arabi al-Mu'ashir (Beirut: al Markaz al-Tsaqofi alArabi), 1992.

Muhammad Abed al-Jabiri, al-Aql al-Siyasi al-Arabi: Muhaddidah wa Tajalliyatuh (Beirut: Markaz Dirasah al-Wihdah al-Arabiyyah), 1992.

Muhammed Abed al-Jabiri, Arab-Islamic Philosophy; A Contemporary Critique (diterjemahkan oleh Burhan dalam buku Kritik Pemikiran Islam; Wacana Baru Filsafat Islam), Yogyakarta, 2003. 